\title{
Antibacterial and antioxidant activity of different extracts obtained from Withania somnifera (Ashwagandha)
}

\author{
Research Article
}

\section{Kumbukgolla W W11, Attanayake A M H S ${ }^{2 *}$, Jayaweera J A A S}

1. Senior Lecturer, Department of Biochemistry, Faculty of Medicine, University of Rajarata, Saliyapura, Anuradhapura, Sri Lanka. 2. PG Scholar, PG Department of Kayachikitsa, National Institute of Ayurveda, Jorawar Singh gate, Amer Road, Jaipur, Rajasthan, India. 3. Senior Lecturer, Department of Microbiology, Faculty of medicine, University of Rajarata, Saliyapura, Anuradhapura, Sri Lanka.

\begin{abstract}
Ashwagandha (Withania somnifera) is widely known as the queen of Indian Ayurveda. The objective of this study was to determine the antioxidant and antibacterial activity of the different parts of the Ashwagandha. The antioxidant activity of different extracts from different parts of Ashwagandha was determined using DPPH free radical scavenging method. Ashwaghanda root inhabiting bacteria was isolated using pour-plate technique. The agar well method and filter paper method were followed to assess the antibacterial activity of the extracts. Ethanol-water extracts $(1: 1 \mathrm{v} / \mathrm{v})$ gave higher yield of extractable matter than methanol extracts. The antioxidant activity of fresh root extract was significantly higher than other parts of the plant (stem and leaves) as well as the plant material bought from open market. The minimal inhibitory concentration (MIC) values of Ethanol-water extract against MRSA, Candida Sp. and Salmonella Sp. were $>256 \mathrm{mg} / \mathrm{L}$. The commensal bacteria (Bacilli) inhabiting Ashwagandha roots displayed mild antibacterial activity against pathogenic $P$. aeruginosa.
\end{abstract}

Key Words: Ashwaghanda, Commensal bacteria, Antibacterial activity, Antioxidant activity, Crude extracts.

\section{Introduction}

The medicinal plant, Ashwaganda ( $W$. somnifera) is commonly known as "Indian winter cherry" or "Indian Ginseng" or "queen of Ayurveda" (1-5). The root smells like a horse is the basis of its' Indian name, "Ashwaganda" (5). The meaning of the Latin word "somnifera" is "sleep inducer" which reflects the stress releasing pharmacological properties of the plant.

Ashwagandha (W. somnifera) has a history over 3000 years being used in Indian Ayurveda and indigenous medicine (6-8). Ashwagandha is a valuable component for over 100 formulations in traditional medicine (9). This herb is well known for its' energy boosting properties whereas the supplements forms are commercially available (10). According to Ayurveda Ashwagandha have various properties. Mainly Ashwagandha has effects of nourishing and strength promoters. It has been described in the Vrunhaniya Gana (Nourishing drugs) and Balya Gana (Strength promoting drugs) (11).

Ashwaghanda inherits wide range of pharmacological significance such as antitumor, antioxidant, anti-inflammatory and immunomodulator

\section{* Corresponding Author:}

Attanayake A M H S

PG Scholar,

PG Department of Kayachikitsa,

National Institute of Ayurveda, Jorawar singh gate,

Amer Road, Jaipur, Rajasthan, India.

Email Id: harshamed@yahoo.com and for the treatment of the disorders of the central nervous system $(1-4,8,12,13)$.

Antioxidant activity of Ashwaghanda roots has been observed previously (14). Ethanol-water mixture is a potential solvent for the extraction of compounds from the plant material for their biological activity whereas the biological properties of Ethanol-water (1:1 $\mathrm{v} / \mathrm{v}$ ) extract of Ashwagandha is lacking in previous work $(14,15)$. Moreover, the biological properties of different parts of the plant are required to be compared with each other because of the root part is more frequently used in Ayurveda than stem and leaves. The aim of this study was to assess the biological properties of different parts of Ashwaghanda herb, particularly the antibacterial aspects which studied into a lesser extent, previously. Moreover, the antioxidant potential of commercially available herbal materials of Ashwaghanda (roots) is examined in comparison with fresh herb to obtain an insight on quality of commercially available products.

The antibacterial activity of Ashwaghanda has been previously mentioned in few studies $(17,18,19)$. With a view of expanding the details given in previously conducted work, here we assayed different extracts of Ashwaghanda (8 different extracts) using 7 species of medically important pathogens (Methicillin resistant $S$. aureus; $P$. aeruginosa; Klebsiella; Salmonella; Enterococcus; E coli; Candida).

\section{Materials and Methods \\ Collection of plant materials}

The plant materials Ashwagandha ( $W$. somnifera) were obtained from the herbal garden at 
Bandaranaike Memorial Ayurvedic Research Institute (BMARI), Colombo, Sri Lanka, under the consultation of manager (Botanist) of the herbal garden. The commercially available roots of W. somnifera were bought from a recognized Ayurvedic product seller shop in Colombo.

\section{Preparation of plant extracts}

The whole plants were separated into the leaves, stem and roots and those were chopped into small pieces. The plant material was dried in $40 \mathrm{C}^{\circ}$ for 1 week time until a constant weight was obtained. Two different solvents (methanol; EtOAc: water 1:1 v/v) were used for the extraction, separately and the volume of the solvent added, was 5 times the weight of the dried plant material used in the extraction. One portion of the plant material was dipped in methanol while the other portion was dipped in EtOAc-water mixture. The solvents and plant materials were shake together for 48 $\mathrm{h}$ in room temperature $\left(32 \mathrm{C}^{\circ}\right)$ using a mechanical shaker. The weights of plant materials and the volume of the solvents used in the extraction were recorded. The solvent portion of extracts were evaporated using a rotary-evaporator and the resulting material was freezedried to obtain solid-powder. Eight different extracts were prepared in total, and these extracts were used for antioxidant and antibacterial assays.

\section{Antioxidant activity assay}

Antioxidant activity of each extract was determined using DPPH free radical scavenging method. A concentrations series $(500 \mathrm{mg} / \mathrm{L} 100 \mathrm{mg} / \mathrm{L} 10$ $\mathrm{mg} / \mathrm{L}$ ) was prepared using extracts to assess the antioxidant potential of each extract. The extracts and DPPH reagent were added in 1:3 ratio and incubated for 30 minutes in the room temperature and in dark environment. The absorbance was obtained using spectrophotometer in $517 \mathrm{~nm}$. The antioxidant activity was recorded as Percentage effect (E \%) and calculated using following equation.

Abs control-Abs sample $\times 100$

Abs control

\section{Antimicrobial assays of different extracts against human pathogens}

For the initial screening of antimicrobial activity, agar well method was conducted. The agar plate dilution method was conducted to determine the individual minimum inhibitory concentration (MIC) values of extracts against medically important pathogenic bacteria.

\section{Microbial cultures}

The Microbial cultures (Methicillin resistant $S$. aureus; $P$. aeruginosa; Klebsiella; Salmonella; Enterococcus; $E$ coli; Candida) were obtained from the culture collection at the Department of Microbiology, Faculty of Medicine and Allied Sciences, Rajarata University of Sri Lanka. All the cultures were human clinical isolates and 4 different isolates (strains) from each species of bacteria were used for assays.

\section{Agar well method}

Agar well method was performed to screen the antibacterial activity of the extracts. The wells were prepared in the MHA plates containing a microbial lawn (Prepared using $0.5 \mathrm{McFarland}$ standard) and each of the extracts were filled into different wells. The MHA plates incubated overnight and observed for a clear zone around the wells.

\section{Agar plate dilution method}

Agar plate dilution method was carried out according to the guidelines provided by British Society of Antimicrobial Chemotherapy (BSAC) (21). A dilution series, starting from $256 \mathrm{mg} / \mathrm{L}$ down to $16 \mathrm{mg} / \mathrm{L}$ was prepared in MHA plates using each extract of the plant. The bacterial inoculum (density equal to 0.5 McFarland-standard) was spotted as a small drop on the surface of the agar and observed for visual growth, after incubating the plates at $37 \mathrm{C}^{\circ}$, overnight.

\section{Isolation of root inhabiting bacteria}

The fresh roots obtained from the plant were rinsed by sterile water and the resulting water extract was cultured in a Muller Hinton Agar (MHA) plate. The bacteria grown in the plate was identified using gram staining and biochemical tests. A small piece of the root was stabbed into another MHA plate and the bacterial growth around the root was observed and growing bacterial species was identified.

\section{Antimicrobial assays using isolated root inhabiting bacteria}

The isolated root inhabiting bacteria (2.4.4) was used for antimicrobial assays against human pathogenic bacteria (Methicillin resistant $S$. aureus MRSA; $P$. aeruginosa; Klebsiella; Salmonella; Enterococcus; E coli; Candida) using filter paper technique. A piece of filter paper was soaked using the isolated bacterial inoculum from the roots and placed on the lawn of pathogenic bacteria, prepared in MHA plates. The plates were observed for an inhibition zone around the filter paper after incubating $37 \mathrm{C}^{\circ}$, overnight.

\section{Results}

\section{Yield of the extractable matter}

Table 1: Yield of extractable matter from different parts of the plant using the solvents, Ethanol water and methanol

\begin{tabular}{|c|c|c|}
\hline $\begin{array}{l}\text { Type of plant } \\
\text { material }\end{array}$ & $\begin{array}{c}\text { Ethanol-water } \\
\text { extract }(1: 1 ; \mathrm{v} / \mathrm{v}) \\
(\% \mathrm{~W} / \mathrm{W})\end{array}$ & $\begin{array}{c}\text { Methanol } \\
\text { extract } \\
(\% ; W / W)\end{array}$ \\
\hline $\begin{array}{l}\text { Fresh Roots from } \\
\text { the plant }\end{array}$ & $2.7 \%$ & $0.5 \%$ \\
\hline $\begin{array}{l}\text { Commercially } \\
\text { available roots }\end{array}$ & $7.8 \%$ & $2.04 \%$ \\
\hline Fresh Stem & $3.14 \%$ & $1.2 \%$ \\
\hline Fresh Leaves & $4.3 \%$ & $2.5 \%$ \\
\hline
\end{tabular}


The weight of crude extract as a percentage of dry weight of the plant material is displayed in table 1 . The highest percentage of extractable matter was obtained from commercially available roots using methanol-water as the solvent. The mean percentage of extractable matter in ethanol-water $(4.48 \%)$ extracts were higher than methanol extracts $(1.56 \%$; Table 1$)$.

\section{Antioxidant activity of different extracts of the plant}

The antioxidant activity of methanol extracts and ethanol-water extracts were highest in fresh roots obtained from the plant. The commercially available root showed significantly lesser antioxidant activity than fresh roots whereas the leaves showed the least antioxidant activity (Table 2). The comparison between methanolic and ethanol-water extract showed that the antioxidant potential was roughly similar in both the extract.

Table 2: Antioxidant activity of extracts obtained from different parts of the plant in Ethanol-water and methanol

\begin{tabular}{|c|c|c|c|c|c|c|}
\hline \multirow{3}{*}{ Extract } & \multicolumn{6}{|c|}{ Antioxidant activity (Percentage effect; E \%) } \\
\hline & \multicolumn{3}{|c|}{$\begin{array}{c}\text { Ethanol-water extract } \\
(1: 1 ; \mathrm{v} / \mathrm{v})\end{array}$} & \multicolumn{3}{|c|}{ Methanol extract } \\
\hline & $\begin{array}{c}500 \\
\mathrm{mg} / \mathrm{L}\end{array}$ & $\begin{array}{c}100 \\
\mathrm{mg} / \mathrm{L}\end{array}$ & $\begin{array}{c}10 \\
\mathrm{mg} / \mathrm{L}\end{array}$ & $\begin{array}{c}500 \\
\mathrm{mg} / \mathrm{L}\end{array}$ & $\begin{array}{c}100 \\
\mathrm{mg} / \mathrm{L}\end{array}$ & $\begin{array}{c}10 \\
\mathrm{mg} / \mathrm{L}\end{array}$ \\
\hline Fresh roots & 93.4 & 27 & 3.8 & 92.9 & 23.5 & 1.9 \\
\hline $\begin{array}{l}\text { Commercially } \\
\text { available roots }\end{array}$ & 29.8 & 5.6 & 0.1 & 31.6 & 5.6 & 1.6 \\
\hline Fresh stem & 18.4 & 5 & 1.1 & 52.9 & 6.3 & 2.2 \\
\hline Fresh leaves & 17.1 & 4.3 & 0.7 & 21.4 & 6.3 & 0.3 \\
\hline
\end{tabular}

\subsection{Antibacterial activity of different extracts of the plant}

The ethanol-water extract of fresh roots showed inhibitory zone (Diameter of the well $12 \mathrm{~mm}$; Diameter of the inhibition zone including the well: $17 \mathrm{~mm}$ ) in 5 $\mathrm{mg} / \mathrm{mL}$ concentration against MRSA, Candida and Salmonella. Other extracts did not show any clear zone around the wells against assayed pathogens (Methicillin resistant $S$. aureus; $P$. aeruginosa; Klebsiella; Salmonella; Enterococcus; E coli; Candida [Table: 3]).

Table 3: Inhibitory activity of different ashwaghanda extracts against human pathogens

\begin{tabular}{|c|c|c|c|}
\hline \multirow[t]{2}{*}{ Organism } & \multicolumn{3}{|c|}{$\begin{array}{l}\text { Antibacterial activity (Inhibition zone } \\
\text { diameter) * }\end{array}$} \\
\hline & Roots (5 mg/ml) & $\begin{array}{l}\text { Stem }(5 \\
\mathrm{mg} / \mathrm{ml})\end{array}$ & $\begin{array}{c}\text { Leaves }(5 \\
\mathrm{mg} / \mathrm{ml})\end{array}$ \\
\hline $\begin{array}{l}\text { Methicillin } \\
\text { resistant } S \text {. aureus }\end{array}$ & $17 \mathrm{~mm}$ & No zone & No zone \\
\hline$P$. aeruginosa & No zone & No zone & No zone \\
\hline Klebsiella & No zone & No zone & No zone \\
\hline Salmonella & $17 \mathrm{~mm}$ & No zone & No zone \\
\hline Enterococcus & No zone & No zone & No zone \\
\hline E coli & No zone & No zone & No zone \\
\hline Candida & $17 \mathrm{~mm}$ & No zone & No zone \\
\hline
\end{tabular}

*Well diameter: $12 \mathrm{~mm}$

Therefore, Agar Plate Dilution Method was conducted using only Ethanol-water extract. According to the Agar plate dilution method MRSA Candida and Salmonella showed MIC $>256 \mathrm{mg} / \mathrm{L}$.
Antibacterial activity of root inhabiting bacteria against pathogenic bacteria

The bacteria isolated from the roots of $W$. somnifera was identified as a gram-positive bacillus. The bacterium in the water which was used to rinse the fresh roots of the plant was similar to the bacteria grown around the stabbed root in the agar plate and both the isolates were pure cultures. This gram-positive bacterium showed mild antibacterial activity (clear zone of $3 \mathrm{~mm}$ width from of the filter paper) against pseudomonas aeruginosa. There was no inhibitory activity exhibited against other bacterial species/strains (Methicillin resistant $S$. aureus; $P$. aeruginosa; Klebsiella; Salmonella; Enterococcus; E coli; Candida).

\section{Discussion}

According to Indian Ayurveda, Ashwagandha has tastes of Madhura (sweet), Tikta (Bitter) and Kashaya (Astrigent). It has Guna (physicopharmacological properties) of Laghu (light) and Snigdha (unctuous). It's Vipaka (final transformation) is Madhura and Veerya (powers that performs action in the body) is Ushna (hot). Ashwagandha helps for longevity and to restore the strength of the body (16).

In the extracting process, ethanol-water extract generated a better yield of crude material than methanol extract which has previously shown using other herbal plant species (15) (Table 1). The antioxidant activity of Ashwagandha root extracts is behind the gallic acid; however, roughly comparable with Phyllanthus emblica which is another potential antioxidant herb used in traditional medicine. Significantly, roots displayed higher antioxidant activity than other parts of the plant (stem and leaves). The plant material bought from open market showed inferior antioxidant activity than the fresh plant material (Table 2).

According to the results obtained by antimicrobial assays of crude extracts against medically important pathogens, MRSA Candida and Salmonella showed inhibition zone in $5 \mathrm{mg} / \mathrm{mL}$ concentration of the ethanol-water extract. Other extracts did not show any clear zone around the wells against the pathogens tested (Methicillin resistant $S$. aureus; $P$. aeruginosa; Klebsiella; Salmonella; Enterococcus; E coli; Candida). The minimum inhibitory concentrations (MICs) obtained by other studies against both gram negative and positive bacteria falls in the range of $0.78 \mathrm{mg} / \mathrm{mL}-153 \mathrm{mg} / \mathrm{Ml}(17,18,19,20)$ where as some other herbal extracts such as tea catechins has shown $50-180 \mu \mathrm{g} / \mathrm{mL}$ MIC value against MRSA (21). The MICs of Ashwagandha extracts, in the range of $0.78 \mathrm{mg} /$ $\mathrm{L}-153 \mathrm{mg} / \mathrm{L}$ can be categorized as having mild to moderate antibacterial activity because of many highly potent antibacterial compounds and extracts display MICs bellow $128 \mu \mathrm{g} / \mathrm{mL}$ when British Society for Antimicrobial Chemotherapy (BSAC), agar plate dilution method is conducted for MIC determination (22). The mild to moderate potential of Ashwagandha in the bacteriology side is further reflected by the fact that major traditional medicine applications of this herb 
basically target the neurological/psychology/energy metabolism aspects of the body $(8,22,23,24,25,27)$.

The commensal bacterium inhabiting the Ashwagndha roots was a Bacilli and surprisingly the microbial colony grown around the root was a pure culture of Bacilli and was same as the culture obtained from the root-rinsed-water. However, this commensal bacterium showed mild inhibitory activity only against Pseudomonas aeruginosa out of the 7 pathogens tested. All other pathogens did not show any inhibitory activity.

\section{Conclusion}

Ethanol-water is a better solvent for higher yield of active compounds than methanol. Ashwagandha root inhabiting bacteria (Bacilli) displayed mild antibacterial activity against pathogenic $P$. aeruginosa. The extracts of this herb showed mild to moderate antibacterial properties, overall. The fresh root extracts of Ashwagandha displayed an impressive antioxidant potential. The highly significant biological activities (antibacterial and antioxidant) were displayed by fresh roots extracts (Ethanol-water and Methanol extracts; Table: 2) compared to commercially available root extracts, fresh stem and fresh leaves. This fact is further evidenced in traditional medicine in-which roots are more frequently used for herbal preparations than leaves and the stem of Ashwaghanda.

\section{Acknowledgements}

We acknowledge Dr. Swarna Kaluthota, Director, Bandaranaike memorial Ayurvedic Research Institute, Colombo for kindly providing us the plant material. Mr. Wajira Wickramasingha, Technical Officer, Faculty of Medicine and Allied Sciences, is acknowledged for giving necessary technical assistance.

\section{References}

1. Gautam A, Thakur M.K, Assessment of Cholinergic Properties of Ashwagandha Leaf-Extract in the Amnesic Mouse Brain. Ann Neurosci. 2016;23:68-75

2. Maurya R, Chemistry and pharmacology of Withania coagulans : an Ayurvedic remedy Taxonomical Classification Phytochemistry Pharmacological Properties. Journal of Pharmacy and Pharmacology.2010; 62: 153-160

3. Rai M.K, Naik S.K, Critical Reviews in Biotechnology Exploring plant tissue culture in Withania somnifera ( $\mathrm{L}$.) Dunal : in vitro propagation and secondary metabolite production. Critical Reviews of Biotechnology. November. 2017;836-850

4. Sanchita, Singh S, Sharma, Bioinformatics approaches for structural and functional analysis of proteins in secondary metabolism in Withania somnifera. Mol Biol Rep. Nov. 2014; 41(11):7323-30

5. Alzoubi K.H, Al A.S, Qosay H, Balas A. Al, El K, Tamam S, Elimat E, Alali F.Q, Withania somnifera root powder protects againist post - traumatic stress disorder - induced memory impairment. Mol. Biol. Rep. October. 2019; 46 (5):4709-4715

6. Pandey V, Ansari W.A, Misra P, Atri N, Withania somnifera : Advances and Implementation of Molecular and Tissue Culture Techniques to Enhance Its Application. Front Plant Sci. August. 2017; 9; 8:1390

7. White P.T, Subramanian C, Motiwala H.F, Cohen M.S, Natural Withanolides in the Treatment of Chronic Diseases. Adv Exp Med Biol. 2016; 928: 329-373

8. Singh R, Das N, Lal P, Misra L, Withanolide A is inherently de novo biosynthesized in roots of the medicinal plant Ashwagandha (Withania somnifera). Physiol Plant. 2008 Jun; 133(2):278-87

9. Sharma R. K, Dash B, Charaka Samhita text with English translation and critical exposition based on Cakrapani Datta's Ayurveda Dipika, Volume 1, Charak suthrasthana 4/8-20, Varanasi; Chowkhamba Sanskrit Series Office; 2019. 86-101p

10. Physiology C, Ajit K Shasany, Chief Scientist , Biotechnology Division, CSIR-Central Institute of Medicinal and Aromatic Plants , P . O .CIMAP, Lucknow-226015 , U. P ., India. 2018

11. Shahriar, M, Hossain, I, Sharmin F.A, Akhter, S, Haque A, Bhuiyan M.A, InVitro Antioxidant and Free Radical Scavenging Activity of Withania Somnifera Root. Iosr Journal of Pharmacy. March. 2013; 38- 47

12. Sun C, Wu Z, Wang Z, Zhang H, Effect of Ethanol / Water Solvents on Phenolic Profiles and Antioxidant Properties of Beijing Propolis Extracts.

Evidence Based Complement Alternative Medicine. 2015; 2015:595393

13. Kuchewar V. V, Borkar M. A, \& Nisargandha M. A, Evaluation of antioxidant potential of Rasayana drugs in healthy human volunteers. Ayu. 2014; 35(1): 46-49

14. Mwitari P.G, Ayeka P.A, Ondicho J, Matu E.N, Bii C.C, Antimicrobial Activity and Probable Mechanisms of Action of Medicinal Plants of Kenya : Withania somnifera , Warbugia ugandensis, Prunus africana and Plectrunthus barbatus. PLoS One. 2013 Jun 13; 8(6):e65619

15. Kothalawala M, Jayaweera J.A.A.S., Arunan S. The emergence of non-albicans candidemia and evaluation of HiChrome Candida differential agar and VITEK2 YST ${ }^{\circledR}$ platform for differentiation of Candida bloodstream isolates in teaching hospital Kandy, Sri Lanka. BMC Microbiol 2019; 19, 136

16. Andrews J.M, Determination of minimum inhibitory concentrations. Journal of Antimicrobial Chemotherapy. 2002;49: 1049-1050

17. Khan B, Fayaz S, Bani S. Kaul A. Suri K.A. Satti N.K. Athar M. Qazi G.N, Augmentation and proliferation of $\mathrm{T}$ lymphocytes and Th-1 cytokines by Withania somnifera in stressed mice. Int Immunopharmacol. 2006 Sep;6(9):1394-403

18. Mahdi A.A, Shukla K.K, Ahmad M.K, Rajender S, Shankhwar S.N, Singh V, Dalela D, Withania somnifera Improves Semen Quality in StressRelated Male Fertility. Evidence-Based 
Complementary and Alternative Medicine. September. 2009; 29; 2011: 576962

19. Dar N.J, Hamid A, Ahmad M, Pharmacologic overview of Withania somnifera, the Indian Ginseng. Cell. Mol. Life Sci.72, 2015; 4445-4460

20. Borah K, Sharma S, Silla Y, Structural bioinformatics-based identification of putative plant based lead compounds for Alzheimer Disease
Therapy. Computational Biology and Chemistry. 2019; Volume 78, Pages 359-366

21. Gupta M, Kaur G, Withania somnifera as a Potential Anxiolytic and Anti-inflammatory Candidate Against Systemic LipopolysaccharideInduced Neuroinflammation. Neuromol Med. 2018;20; 343-362. 